\title{
DIFFUSION KINETICS AND CHARACTERIZATION OF BORIDED AISI H10 STEEL
}

\author{
KINETIKA DIFUZIJE IN KARAKTERIZACIJA BORIRANEGA \\ JEKLA AISI H10
}

\author{
Ibrahim Gunes, Melih Ozcatal \\ Department of Metallurgical and Materials Engineering, Faculty of Technology, Afyon Kocatepe University, 03200 Afyonkarahisar, Turkey \\ igunes@aku.edu.tr
}

Prejem rokopisa - received: 2014-09-22; sprejem za objavo - accepted for publication: 2014-10-17

doi: $10.17222 / \mathrm{mit} .2014 .238$

\begin{abstract}
In this study, case properties and diffusion kinetics of the AISI H10 steel borided in Ekabor-II powder were investigated by conducting a series of experiments at temperatures of $(1123,1173$ and 1223$) \mathrm{K}$ for $(2,4$ and 6$) \mathrm{h}$. The boride layer was characterized with light microscopy, X-ray diffraction technique and micro-Vickers hardness tester. The X-ray diffraction analysis of the boride layers on the surfaces of the steels revealed the existence of $\mathrm{FeB}, \mathrm{Fe}_{2} \mathrm{~B}, \mathrm{CrB}, \mathrm{Cr}_{2} \mathrm{~B}$ and MoB compounds. Depending on the chemical compositions of the substrates and boriding time, the boride-layer thickness on the surface of the steel ranged from $12.86 \mu \mathrm{m}$ to $63.72 \mu \mathrm{m}$. The hardness of the boride compounds formed on the surfaces of the steels ranged from $1648 \mathrm{HV}_{0.05}$ to $1964 \mathrm{HV}_{0.05}$, whereas the Vickers-hardness value of the untreated steel was $306 \mathrm{HV}_{0.05}$. The activation energy $(Q)$ of the borided steel was $160.594 \mathrm{~kJ} / \mathrm{mol}$. The growth kinetics of the boride layer formed on the AISI H10 steel and its thickness were also investigated.
\end{abstract}

Keywords: AISI H10, boride layer, microhardness, kinetics, activation energy

V tej študiji so bile preiskovane lastnosti in kinetika difuzije v jeklu AISI H10, boriranem v prahu Ekabor-II (2, 4 in 6$)$ h na temperaturah $(1123,1173$ in 1223) K. Boridni sloj je bil okarakteriziran s svetlobno mikroskopijo, z rentgensko difrakcijo in merjenjem mikrotrdote po Vickersu. Rentgenska difrakcija boridnega sloja je odkrila prisotnost naslednjih spojin: FeB, Fe ${ }_{2} \mathrm{~B}$, $\mathrm{CrB}, \mathrm{Cr}_{2} \mathrm{~B}$ in $\mathrm{MoB}$.

Odvisno od kemijske sestave podlage in časa boriranja je bila debelina sloja borida na površini jekla med 12,86 um in 63,72 um. Trdota boridov, nastalih na površini jekla, je bila med $1648 \mathrm{HV}_{0,05}$ in $1964 \mathrm{HV}_{0,05}$, medtem ko je bila Vickersova trdota neobdelanega jekla $306 \mathrm{HV}_{0,05}$. Aktivacijska energija $(Q)$ pri boriranju jekla je bila $160,594 \mathrm{~kJ} / \mathrm{mol}$. Preiskovana je bila tudi kinetika rasti in debelina boridnega sloja na jeklu AISI H10.

Ključne besede: AISI H10, sloj borida, mikrotrdota, kinetika, aktivacijska energija

\section{INTRODUCTION}

Boriding, or boronizing, is a thermochemical surface-hardening process that can be applied to a wide variety of ferrous, nonferrous and cermet materials. The process involves heating a well-cleaned material in the range of $973 \mathrm{~K}$ to $1373 \mathrm{~K}$, preferably for $1 \mathrm{~h}$ to $12 \mathrm{~h}$, in contact with a boronaceous solid powder (boronizing compound), paste, liquid, plasma, gaseous or electrochemical medium. ${ }^{1-7}$

Boron atoms, due to their relatively small size (an atomic radius of $0.09 \mathrm{~nm}$ ) and very mobile nature can diffuse easily into ferrous alloys (an atomic radius of $0.124 \mathrm{~nm}$ ) forming $\mathrm{FeB}$ and $\mathrm{Fe}_{2} \mathrm{~B}$ intermetallic, nonoxide, ceramic borides. The diffusion of $\mathrm{B}$ into steel results in the formation of iron borides $\left(\mathrm{FeB}\right.$ and $\mathrm{Fe}_{2} \mathrm{~B}$ ) and the thickness of the boride layer is determined by the temperature and time of the treatment. ${ }^{8-12}$

The basic advantage of boriding is that boride has a high melting point and high hardness at elevated temperatures and, consequently, researches of the boriding of transition metals have been accelerated in the recent decade, particularly for the applications in the production of cutting tools and heavy gears, and in the automotive, casting, textile, food-processing, packaging and ceramic industries where huge friction-dependent energy losses and intensive corrosion and wear occur. ${ }^{13-15}$ In this study, the AISI H10 steel was borided considering these advantages of boriding. The characterization and growth diffusion of the obtained boride layers were calculated. The main objective of this study was to investigate the diffusion kinetics and the effects of the processing parameters such as the temperature, the time and the chemical composition on the boride layers formed on the AISI H10 steel after powder-pack boriding at different processing temperatures and times.

\section{EXPERIMENTAL DETAILS}

\subsection{Boriding and characterization}

The AISI H10 steel essentially contained mass fractions $0.32 \% \mathrm{C}, 3.15 \% \mathrm{Cr}, 2.90 \% \mathrm{Mo}, 0.65 \% \mathrm{~V}$ and $0.40 \% \mathrm{Mn}$. The test specimens were cut into dimensions of $\varnothing 25 \mathrm{~mm} \times 8 \mathrm{~mm}$, ground up to $1200 \mathrm{G}$ and polished using a diamond solution. The boriding heat treatment was carried out in a solid medium con- 
taining an Ekabor-II powder mixture placed in an electrical-resistance furnace operating at temperatures of (1123, 1173 and 1223) $\mathrm{K}$ for $(2,4$ and 6) $\mathrm{h}$ under atmospheric pressure. The microstructures of the polished and etched cross-sections of the specimens were observed under a Nikon MA100 light microscope. The presence of borides formed in the coating layer was confirmed with X-ray diffraction equipment (Shimadzu XRD 6000) using $\mathrm{Cu}-K_{\alpha}$ radiation. The thickness of borides was measured with a digital thickness-measuring instrument attached to the light microscope (Nikon MA100). The hardness measurements of the boride layer on each steel and of the untreated steel substrate were made on the cross-sections using a Shimadzu HMV-2 Vickers indenter with a $50 \mathrm{~g}$ load.

\subsection{Evaluation of the activation energy of boron diffusion}

In order to study the diffusion mechanism, borided AISI H10 steel was used for this purpose. It is assumed that boride layers grow parabolically in the direction of the diffusion flux and perpendicular to the substrate surface. So, the time dependence of the boride-layer thickness can be described with Equation (1):

$$
x^{2}=D t
$$

where $x$ is the depth of the boride layer $(\mathrm{mm}), t$ is the boriding time (s) and $D$ is the boron diffusion coefficient through the boride layer. It is a well-known fact that the main factor limiting the growth of a layer is the diffusion of boron into the substrate. It is possible to argue that the relationship between the growth-rate constant $D$, the activation energy $Q$, and the temperature $T$ in Kelvin, can be expressed as an Arrhenius equation (Equation (2)):

$$
D=D_{0} \exp \left(-\frac{Q}{R T}\right)
$$

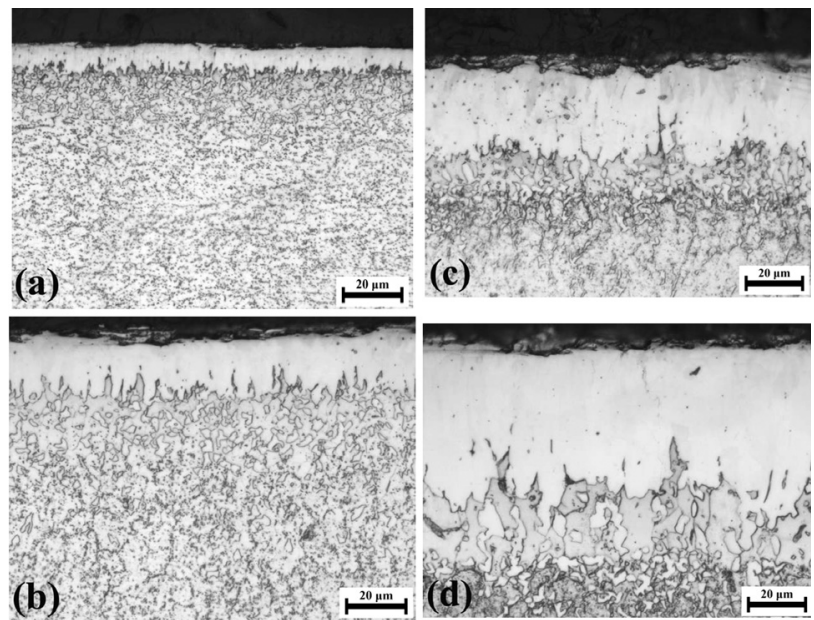

Figure 1: Cross-sections of borided AISI H10 steel: a) $1123 \mathrm{~K}-2 \mathrm{~h}$, b) $1123 \mathrm{~K}-6 \mathrm{~h}$, c) $1223 \mathrm{~K}-2 \mathrm{~h}$, d) $1223 \mathrm{~K}-6 \mathrm{~h}$

Slika 1: Prečni prerez boriranega jekla AISI H10: a) $1123 \mathrm{~K}-2$ h, b) $1123 \mathrm{~K}-6 \mathrm{~h}, \mathrm{c}) 1223 \mathrm{~K}-2 \mathrm{~h}, \mathrm{~d}) 1223 \mathrm{~K}-6 \mathrm{~h}$ where $D_{0}$ is a pre-exponential constant, $Q$ is the activation energy $(\mathrm{J} / \mathrm{mol}), T$ is the absolute temperature in Kelvin and $R$ is the ideal gas constant $(\mathrm{J} /(\mathrm{mol} \mathrm{K}))$.

The activation energy for the boron diffusion in a boride layer is determined with the slope obtained in the plot of $\ln D$ vs. 1/T, using Equation (3):

$$
\ln D=\ln D_{0}-\frac{Q}{R T}
$$

\section{RESULTS AND DISCUSSION}

\subsection{Characterization of boride coatings}

Light micrographs of the cross-sections of the borided AISI H10 steel at the temperatures of $1123 \mathrm{~K}$ and $1223 \mathrm{~K}$ for $2 \mathrm{~h}$ and $6 \mathrm{~h}$ are shown in Figure 1. As can be seen the borides formed on the AISI H10 substrate have a saw-tooth morphology. It was found that the coating/matrix interface and the matrix can be significantly distinguished and the boride layer has a columnar structure. Depending on the chemical compositions of the substrates, the boriding time and temperature, the boride-layer thickness on the surface of the AISI H10 steel ranged from $12.86 \mu \mathrm{m}$ to $63.72 \mu \mathrm{m}$ in Figure 2.

Figure 3 gives the XRD patterns obtained at the surface of the borided AISI H10 steel at $1123 \mathrm{~K}$ and $1223 \mathrm{~K}$ for the treatment times of $2 \mathrm{~h}$ and $6 \mathrm{~h}$. The XRD patterns show that the boride layer consists of borides such as $\mathrm{MB}$ and $\mathrm{M}_{2} \mathrm{~B}(\mathrm{M}=$ metal: $\mathrm{Fe}, \mathrm{Cr})$. The XRD results showed that the boride layers formed on the $\mathrm{H} 10$ steel contained $\mathrm{FeB}, \mathrm{Fe}_{2} \mathrm{~B}, \mathrm{CrB}, \mathrm{Cr}_{2} \mathrm{~B}$ and $\mathrm{MoB}$ phases (Figures 3a to 3d.)

Microhardness measurements were carried out along a line from the surface to the interior in order to see the variations in the hardness of the boride layer, the transition zone and the matrix, respectively. The microhardness of the boride layers was measured at 10 different locations at the same distance from the surface and the

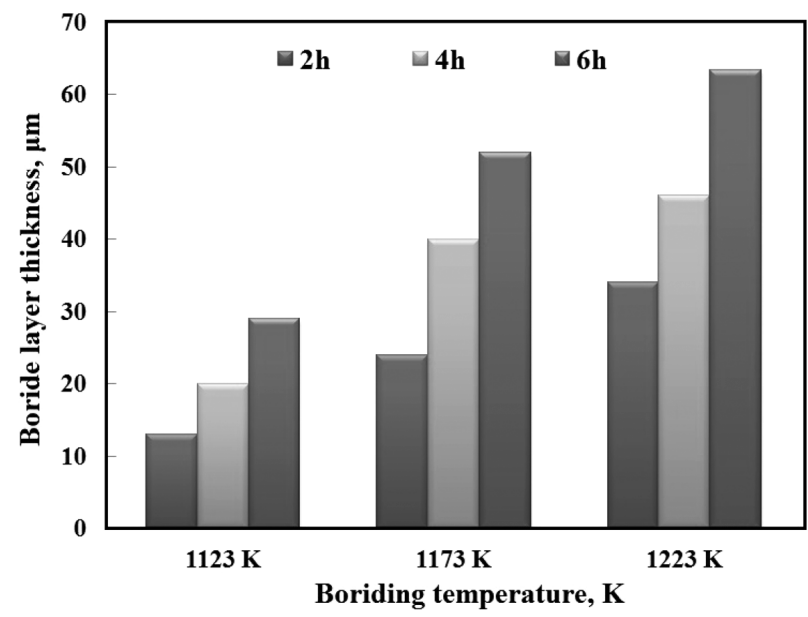

Figure 2: Thickness values of boride layers with respect to boriding time and temperature

Slika 2: Debelina borirane plasti glede na čas in temperaturo boriranja 

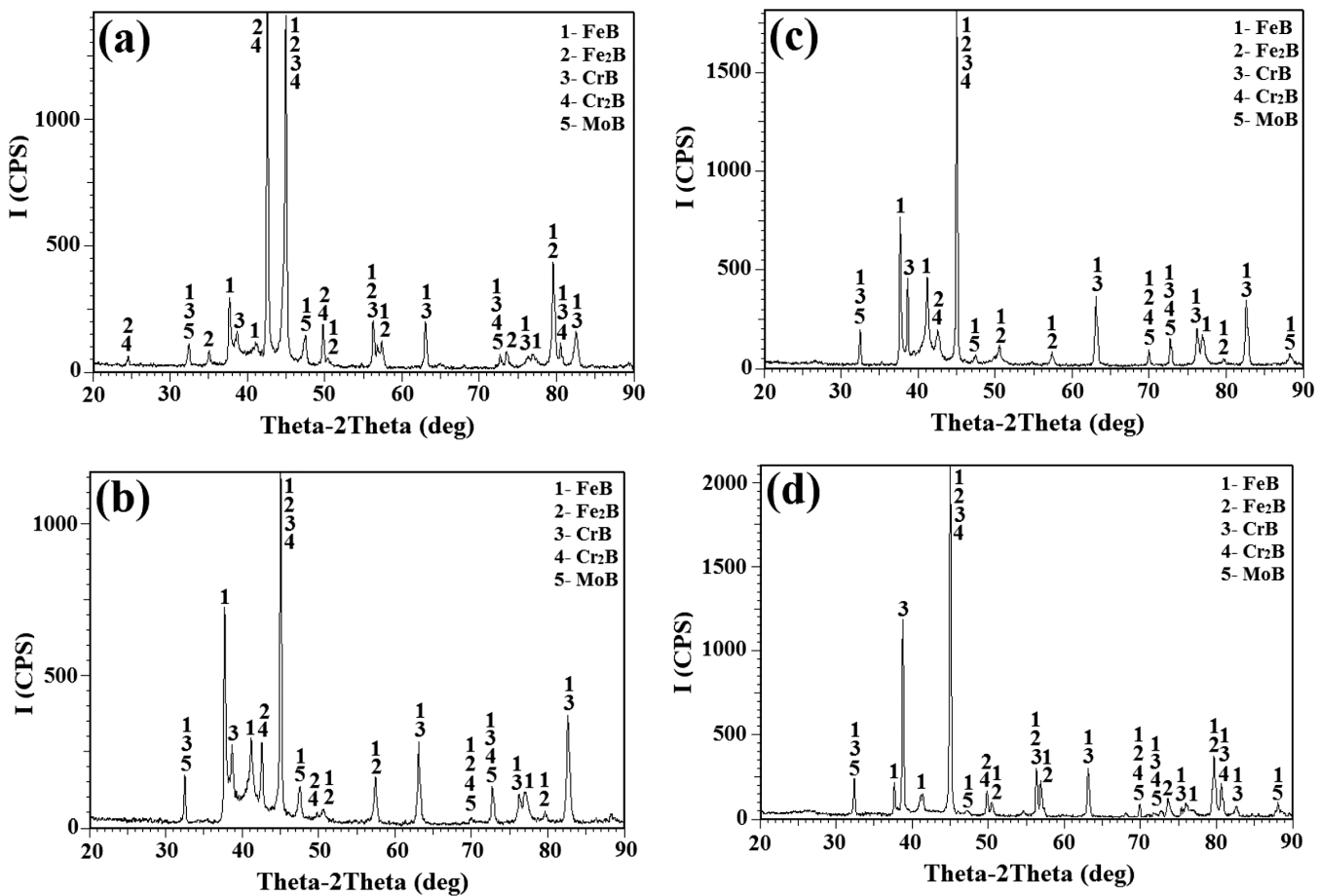

Figure 3: X-ray diffraction patterns of borided AISI H10 steel: a) $1123 \mathrm{~K}-2 \mathrm{~h}$, b) $1123 \mathrm{~K}-6 \mathrm{~h}, \mathrm{c}) 1223 \mathrm{~K}-2 \mathrm{~h}$, d) $1223 \mathrm{~K}-6 \mathrm{~h}$ Slika 3: Rentgenogrami boriranega jekla AISI H10: a) $1123 \mathrm{~K}-2 \mathrm{~h}$, b) $1123 \mathrm{~K}-6 \mathrm{~h}$, c) $1223 \mathrm{~K}-2 \mathrm{~h}$, d) $1223 \mathrm{~K}-6 \mathrm{~h}$

average value was taken as the hardness. The results of the microhardness measurements carried out on the cross-sections, along the line from the surface to the interior are presented in Figure 4. The hardness of the boride layer formed on the AISI H10 steel varied between $1648 \mathrm{HV}_{0.05}$ and $1964 \mathrm{HV}_{0.05}$. On the other hand, the Vickers hardness value for the untreated AISI H10 steel was $306 \mathrm{HV}_{0.05}$. When the hardness of the boride layer is compared with the matrix, the boride-layer hardness is approximately five times larger than that of the matrix.

\subsection{Kinetics}

In this study, the effects of the processing temperature and boriding time on the growth kinetics of a

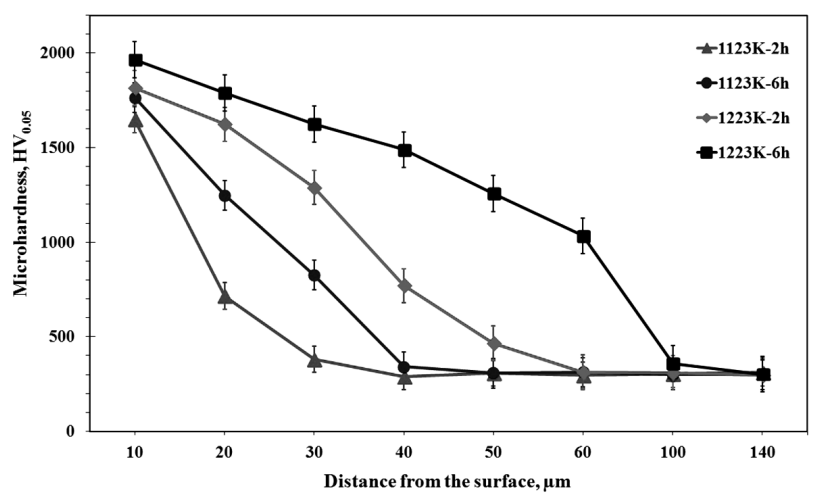

Figure 4: Hardness variation with the depth for the borided AISI H10 steel

Slika 4: Spreminjanje trdote po globini boriranega jekla AISI H10 boride layer were also investigated. The kinetic parameters such as the processing temperature and time must be known for the control of the boriding treatment. Figure 5 shows the time dependence of the squared value of the boride-layer thickness at increasing temperatures. This evolution followed the parabolic growth law where the diffusion of boron atoms is a thermally activated phenomenon. The growth-rate constant $D$ at each boriding temperature can be easily calculated with Equation (1).

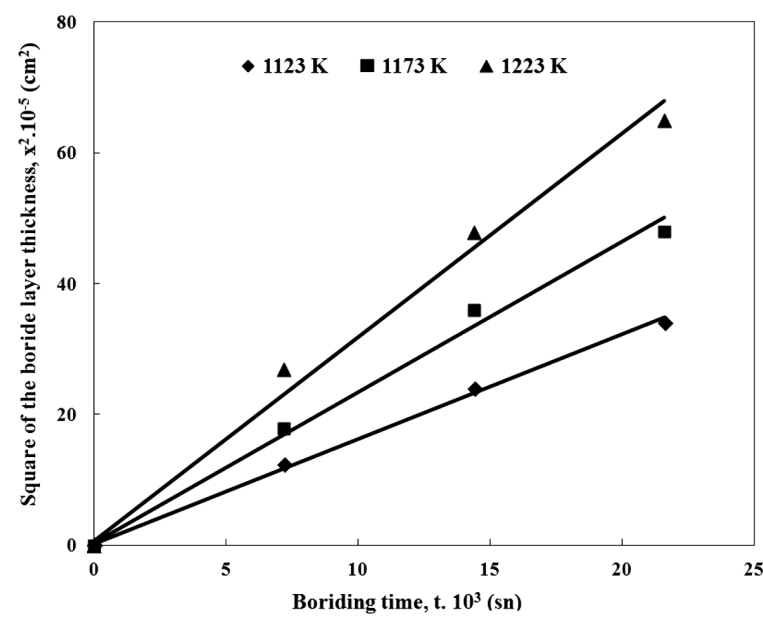

Figure 5: Time dependence of squared boride-layer thickness at increasing temperatures

Slika 5: Casovna odvisnost kvadrata debeline boridne plasti pri naraščajoči temperaturi 
I. GUNES, M. OZCATAL: DIFFUSION KINETICS AND CHARACTERIZATION OF BORIDED AISI H10 STEEL

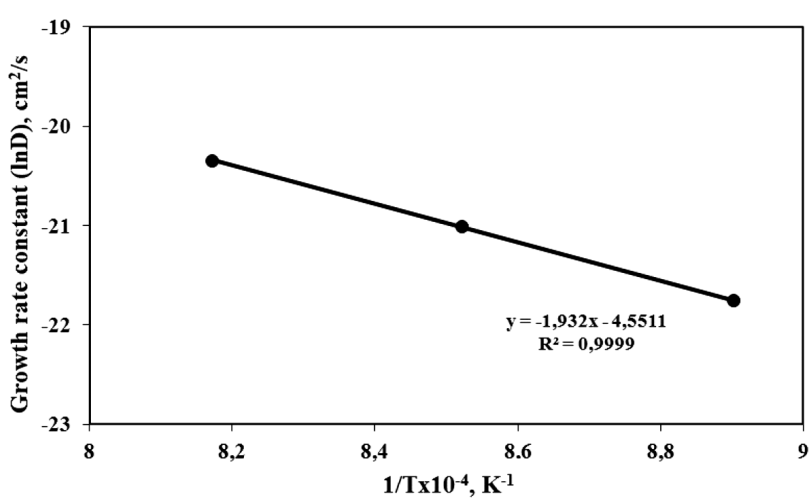

Figure 6: Temperature dependence of the growth-rate constant according to the Arrhenius equation

Slika 6: Temperaturna odvisnost konstante rasti, skladna z Arrheniusovo enačbo

Table 1: Growth-rate constant $(D)$ as the function of boriding temperature

Tabela 1: Konstanta hitrosti rasti $(D)$ v odvisnosti od temperature boriranja

\begin{tabular}{|c|c|c|c|}
\hline \multirow{2}{*}{ Material } & \multicolumn{3}{|c|}{ Growth-rate constant $\left(\mathrm{cm}^{2} \mathrm{~s}^{-1}\right)$} \\
\cline { 2 - 4 } & $1123 \mathrm{~K}$ & $1173 \mathrm{~K}$ & $1223 \mathrm{~K}$ \\
\cline { 2 - 4 } & $5.58 \times 10^{-10}$ & $9.67 \times 10^{-10}$ & $1.18 \times 10^{-9}$ \\
\hline
\end{tabular}

As a result, the calculated growth-rate constants at three temperatures, $(1123,1173$ and 1223$) \mathrm{K}$, are $(5.58 \times$ $10^{-10}, 9.67 \times 10^{-10}$, and $\left.1.18 \times 10^{-9}\right) \mathrm{cm}^{2} \mathrm{~s}^{-1}$ for the borided AISI H10 steel. Table 1 lists the calculated values of the growth constant for each boriding temperature.

Figure 6 describes the temperature dependence of the growth-rate constant. The plot of $\ln D$ as a function of the reciprocal temperature exhibits a linear relation-

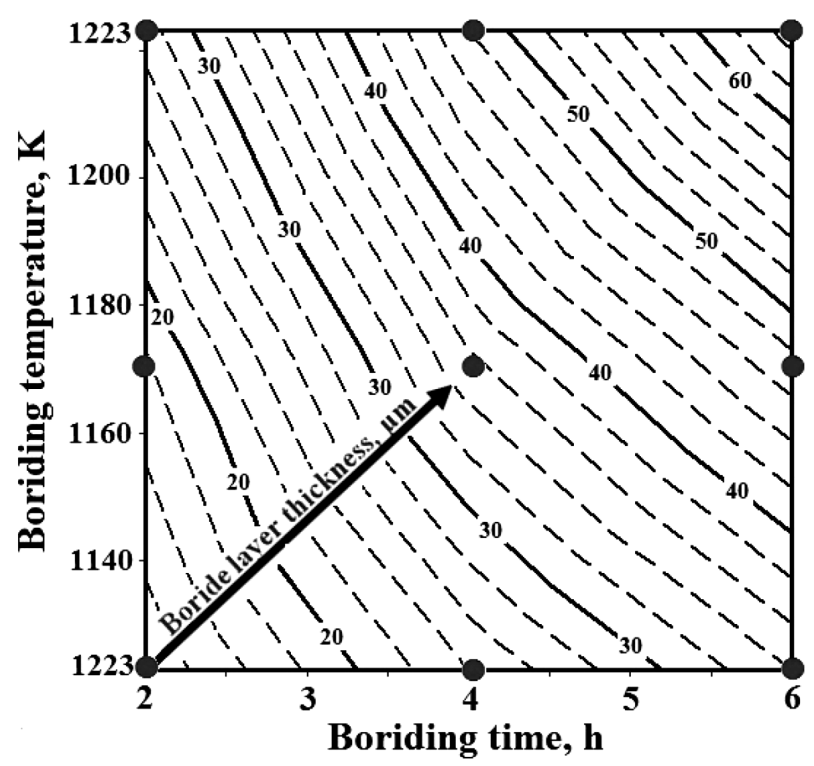

Figure 7: Contour diagram describing the evolution of boride-layer thickness as a function of boriding parameters

Slika 7: Konturni diagram, ki opisuje debelino plasti borida v odvisnosti od parametrov pri boriranju ship according to the Arrhenius equation. The boron activation energy can be easily obtained from the slope of the straight line presented in Figure 6. The value of the boron activation energy was then determined as $160.594 \mathrm{~kJ} / \mathrm{mol}$ for the borided AISI H10 steel.

Table 2 compares the obtained value of energy $(160.594 \mathrm{~kJ} / \mathrm{mol})$ with the data found in the literature. It is seen that the reported values of the boron activation energy depended on the chemical composition of the substrate and the used boriding method. The calculated value in this study is comparable with the values reported in the literature as seen in Table 2. ${ }^{16-21}$

Table 2: Comparison of the activation-energy values for diffusion of boron with respect to different boriding media and substrates

Tabela 2: Primerjava aktivacijske energije za difuzijo bora glede na različne medije in snovi pri boriranju

\begin{tabular}{|l|c|c|c|c|}
\hline \multicolumn{1}{|c|}{ Steel } & $\begin{array}{c}\text { Temperature } \\
\text { range (K) }\end{array}$ & $\begin{array}{c}\text { Boriding } \\
\text { medium }\end{array}$ & $\begin{array}{c}\text { Activation } \\
\text { energy } \\
(\mathrm{kJ} / \mathrm{mol})\end{array}$ & $\begin{array}{c}\text { Refe- } \\
\text { rences }\end{array}$ \\
\hline AISI 8620 & $973-1073$ & Plasma paste & 99.77 & 16 \\
\hline AISI W1 & $1123-1323$ & Pack & 177.8 & 17 \\
AISI 52100 & $1123-1223$ & Pack & 269 & 18 \\
\hline AISI 1035 & $1073-1273$ & Salt bath & 227.5 & 19 \\
\hline AISI H13 & $1073-1223$ & Powder & 186.2 & 20 \\
\hline AISI H13 & $1073-1223$ & Salt bath & 244 & 21 \\
\hline AISI H10 & $1123-1223$ & Pack & 160.594 & $\begin{array}{c}\text { Present } \\
\text { study }\end{array}$ \\
\hline
\end{tabular}

A contour diagram describing the evolution of the boride-layer thickness as a function of the boriding parameters (the time and the temperature) is shown in Figure 7. This contour diagram can be used for two purposes: (1) to predict the coating-layer thickness with respect to the processing parameters, namely, the time and temperature; (2) to determine the value of the processing time and temperature for obtaining a predetermined coatinglayer thickness. ${ }^{22}$ The boride layer increased with an increase in the boriding time and temperature for the borided AISI H10 steel.

\section{CONCLUSIONS}

The following conclusions may be derived from the present study.

- The boride types formed on the surface of the hotwork tool steel have columnar structures.

- The boride-layer thickness obtained on the surface of the AISI H10 steel was 12.86-63.72 $\mu \mathrm{m}$, depending on the chemical compositions of the substrates.

- The multiphase boride coatings that were thermochemically grown on the AISI H10 steel consisted of the $\mathrm{FeB}, \mathrm{Fe}_{2} \mathrm{~B}, \mathrm{CrB}, \mathrm{Cr}_{2} \mathrm{~B}$ and $\mathrm{MoB}$ phases.

- The surface hardness of the borided steel was in the range of 1648-1964 $\mathrm{HV}_{0.05}$, while for the untreated steel it was $306 \mathrm{HV}_{0.05}$. 
- The boron activation energy was estimated to be $160.594 \mathrm{~kJ} / \mathrm{mol}$ for the borided AISI H10 steel.

- A contour diagram relating the boride-layer thickness to the boriding parameters (the time and the temperature) was proposed. It can be used as a simple tool to select the optimum boride layer for a practical utilization of this kind of material.

\section{REFERENCES}

${ }^{1}$ A. K. Sinha, Boriding (Boronizing), ASM handbook, vol. 4, ASM International, OH, USA 1991, 437-447

${ }^{2} \mathrm{~S}$. Taktak, Tribological behaviour of borided bearing steels at elevated temperatures, Surface and Coatings Technology, 201 (2006), 2230-2236, doi:10.1016/j.surfcoat.2006.03.032

${ }^{3}$ I. Gunes, Tribological behavior and characterization of borided cold-work tool steel, Mater. Tehnol., 48 (2014) 5, 765-769

${ }^{4}$ C. Bindal, A. H. Ucisik, Characterization of borides formed on impurity-controlled chromium-based low alloy steels, Surface and Coatings Technology, 122 (1999) 2-3, 208-213, doi:10.1016/S02578972(99)00294-7

${ }^{5}$ M. Erdogan, I. Gunes, A. Dalar, Investigation of Corrosion Behavior of Borided Gear Steels, Transactions of the Indian Institute of Metals, 67 (2014) 2, 291-297, doi:10.1007/s12666-013-0329-8

${ }^{6}$ G. Kartal, O. L. Eryilmaz, G. Krumdick, A. Erdemir, S. Timur, Kinetics of Electrochemical Boriding of Low Carbon Steel, Appl. Surf. Sci., 257 (2011) 15, 6928-6934, doi:10.1016/j.apsusc.2011.03.034

${ }^{7}$ M. Keddam, M. Kulka, N. Makuch, A. Pertek, L. Maldzinski, A kinetic model for estimating the boron activation energies in the $\mathrm{FeB}$ and $\mathrm{Fe}_{2} \mathrm{~B}$ layers during the gas-boriding of Armco iron: Effect of boride incubation times, Appl. Surf. Sci., 298 (2014), 155-163, doi:10.1016/j.apsusc.2014.01.151

${ }^{8}$ I. Gunes, Wear behaviour of plasma paste boronized of AISI 8620 steel with borax and $\mathrm{B}_{2} \mathrm{O}_{3}$ paste mixtures, Journal of Materials Science and Technology, 29 (2013) 7, 662-668, doi:10.1016/j.jmst. 2013.04.005

${ }^{9}$ J. H. Yoon, Y. K. Jee, S. Y. Lee, Plasma paste boronizing treatment of the stainless steel AISI 304, Surface and Coatings Technology, 112 (1999), 71-75, doi:10.1016/S0257-8972(98)00743-9
${ }^{10}$ O. Ozdemir, M. A. Omar, M. Usta, S. Zeytin, C. Bindal, A. H. Ucisik, An investigation on boriding kinetics of AISI 316 stainless steel, Vacuum, 83 (2008), 175-179, doi:10.1016/j.vacuum.2008.03.026

${ }^{11}$ I. Ozbek, C. Bindal, Kinetics of borided AISI M2 high speed steel, Vacuum, 86 (2011) 4, 391-397, doi:10.1016/j.vacuum.2011.08.004

${ }^{12}$ I. Gunes, Kinetics of borided gear steels, Sadhana, 38 (2013) 3, 527-541, doi:10.1007/s12046-013-0138-0

${ }^{13}$ A. Kilic, G. Kartal, M. Urgen, S. Timur, Effects of electrochemical boriding process parameters on the formation of titanium borides, Surface Engineering and Applied Electrochemistry, 49 (2013) 2, 168-175, doi:10.3103/S1068375513020051

${ }^{14} \mathrm{C}$. Li, B. Shen, G. Li, C. Yang, Effect of boronizing temperature and time on microstructure and abrasion wear resistance of $\mathrm{Cr} 12 \mathrm{Mn} 2 \mathrm{~V} 2$ high chromium cast iron, Surface and Coatings Technology, 202 (2008) 24, 5882-5886, doi:10.1016/j.surfcoat.2008.06.170

${ }^{15}$ M. Erdogan, I. Gunes, Corrosion Behavior and Microstructure of Borided Tool Steel, Revista Matéria, 20 (2015) 2, 523-529, doi:10.1590/S1517-707620150002.0052

${ }^{16}$ I. Gunes, S. Ulker, S. Taktak, Kinetics of plasma paste boronized AISI 8620 steel in borax paste mixtures, Protection of Metals and Physical Chemistry of Surfaces, 49 (2013) 5, 567-573, doi:10.1134/ S2070205113050122

${ }^{17}$ K. Genel, I. Ozbek, C. Bindal, Kinetics of boriding of AISI W1 steel, Materials Science and Engineering A, 347 (2003) 1-2, 311-314, doi:10.1016/S0921-5093(02)00607-X

${ }^{18}$ Y. Kayali, I. Gunes, S. Ulu, Diffusion kinetics of borided AISI 52100 and AISI 440C steels, Vacuum, 86 (2012) 10, 1428-1434, doi:10.1016/j.vacuum.2012.03.030

${ }^{19}$ A. Kaouka, O. Allaoui, M. Keddam, Growth kinetics of the boride layers formed on SAE 1035 steel, Materiaux et Techniques, 101 (2013) 7, 705-713, doi:10.1051/mattech/2014003

${ }^{20}$ K. Genel, Boriding kinetics of H13 steel, Vacuum, 80 (2006) 5, 451-457, doi:10.1016/j.vacuum.2005.07.013

${ }^{21} \mathrm{~S}$. Taktak, A study on the diffusion kinetics of borides on boronized Cr-based steels, Journal of Materials Science, 41 (2006) 22, 7590-7596, doi:10.1007/s10853-006-0847-4

${ }^{22}$ O. Kahvecioglu, V. Sista, O. L. Eryilmaz, A. Erdemir, S. Timur, Ultra-fast boriding of nickel aluminide, Thin Solid Films, 520 (2011) 5, 1575-1581, doi:10.1016/j.tsf.2011.08.077 